\title{
SWOT Analysis on the Construction of Characteristic Specialty-oriented Courses in Local Universities under the New Engineering
}

\author{
LUO Qiubin, ZHOU Xueyan*, ZHENG Lan, MAO Yan and REN Xiaolu \\ College of Engineering, Harbin University, 150086
}

\begin{abstract}
With the development of new engineering, local universities have new opportunities for characteristic specialty development. Taking the example of building electricity and intelligent specialties, this paper analyzes the construction of special courses in local universities against the background of the new engineering by means of SWOT analysis method and summarizes the experience so as to provide assistance in the specialty development, the student development and local economic development.
\end{abstract}

Keywords-New engineering; Characteristic specialty in local universities; Directional course group; SWOT

\section{INTRODUCTION}

On April 8, 2017, the Ministry of Education convened the new Engineering Construction Seminar at Tianjin University, and above 60 universities jointly discussed the new engineering construction vision and actions. The Ministry of Education prepared to divide universities into engineering advantage universities, comprehensive universities, and local universities, to carry out the research, of which local applied universities are generally undergraduate universities that are directly subordinated to provincial and municipal level and take applied type as the school-running orientation, rather than taking scientific research as the school-running orientation. Such universities need to use the local resources, dock with the development demand of local economic society and the enterprise technology innovation requirements, deepen the integration of production and education, school-enterprise cooperation, collaborated talent cultivation, promote the transformation and upgrading of traditional engineering, carry out the research and practice of new engineering in local universities. Up till 2020, the new generation of information technology industry, electronic equipment, high-grade CNC machine tools and robots, and new materials of our country will become the specialties with the biggest talent gap, of which the talent gap for the new generation of information technology industry will reach to $7,500,000$ people. Up till 2025, the talent gap for the new generation of information technology industry will reach to $9,500,000$ people, and the talent gap for the electronic equipment will reach to above 9 million people. In combination with the actual development conditions of our school, the Building Electricity and Intelligent Specialty was finally declared in 2014 and 2015 respectively, and the specialty is a new cross-type applied specialty that integrates civil engineering, electronics, computer and other specialty characteristics, and it started to officially recruit students since 2016, and currently, there are totally 104 students at school. The Building Electricity and Intelligent Specialty belongs to a new cross-discipline specialty, and there are merely 89 universities nationwide setting the specialty, and most of them are distributed at Jiangsu and Zhejiang areas, and within Heilongjiang Province, there are only two universes, including Harbin Institute of Technology and Harbin University, and the school-running orientations are different, Harbin Institute of Technology mainly cultivates scientific research talents, and most graduates cannot directly supply the development of local economic society. The bidding and recruitment of the specialty are based on the original intention of serving the development of local economic society, and belong to a major measure for the development of new engineering, so it is still worth studying how to operate the specialty.

In various evaluation methods, SWOT analysis is widely applied in the education link with its simple and fast strengths. SWOT represents Strength, Weakness, Opportunity and Threat which respectively mean 优势, 劣势, 机遇, 威胁 in Chinese. This paper plans to use SWOT analysis method and use the Building Electricity and Intelligent Specialty as the example, and analyze the opportunities and challenges for the characteristic specialty-oriented courses in local universities under the background of new engineering, and is expected to summarize rules, and provide better support for the application of new engineering.

\section{CURRENT STATUS OF THE DOMESTIC AND OVERSEAS} RESEARCH ABOUT THE CONSTRUCTION OF NEW ENGINEERING

The construction of characteristic applied undergraduate universities is one of the important projects for Heilongjiang to execute the Construction Plan for Constructing a Province with a Powerful Higher Education, and after the talents cultivated thereby complete their studies, most of them will be directly employed, so the main cultivation objective for these universities is how to combine market demand, and provide high-quality talent supply to the society.

The fast development of new engineering has absorbed the international experience for the development of new economy abroad, and taken the American development course as the 
example; in 1970s, microelectronics, computer technology, program-controlled exchange and the internet were expanded to the overall economic entity until 1990s, and the delay therein was quite clear. Since talent cultivation requires certain time to adapt to the new technology and new industrial development, the knowledge and skills of talents requested for the information industry cannot be solved through simple training, and it requires the entire education system to make corresponding adjustment. American higher education system was started from the beginning of 1970 s, and used above 20 years of time to adapt to the talent resource transformation demand incurred by information technology reform, and also completed the after-war higher education structural reform itself, and generated benign interaction with American new economy. After the outbreak of the financial crisis in 2008, America executed "reindustrialization" strategy. In July, 2009, American Manufacturing Industry Alliance published the report called Creating a Better Future for America, and requested the government to adopt measures from trade policy, skill training, investment R\&D and other aspects to protect the development of manufacturing industry, and American engineering education corresponded to the strategy.

At home, we have the world's largest scale of engineering education. In 2016, there were 5,380,000 engineering undergraduate students at school, 1,230,000 graduates, 17,037 specialty layouts, and the engineering students at school can occupy about $1 / 3$ of the total students at school for higher education. The quality of engineering education has decided the overall quality of higher education in our country to a great extent. But at the current period when traditional specialty employment is difficult, the status of no available counterpart talents for emerging industry is quite common. It can be easily seen from the series of measures of the Ministry of Education, the basic requirement for our country to deepen education reform is to positively develop "new engineering", while the new engineering reform of local undergraduate universities will serve the local economy more directly.

\section{SWOT ANALYSIS ON THE CONSTRUCTION OF SPECIALTY-ORIENTED COURSES}

\section{A. Strength Analysis}

The Building Electricity and Intelligent Specialty is the new specialty serving the local characteristics, and after the graduation, students are mainly oriented to the building industry engineering unit, government department, planning department, economic management department, design unit, construction enterprise, scientific research unit, schools, enterprises and public institutions or departments, and then engaged in scientific research, teaching, technical development, engineering design and construction as well as planning management and other work. In the recent years, the local universities have developed fast, and the conditions of all aspects are largely improved. Firstly, the hardware conditions can support characteristic specialty development, and specifically speaking, the new professional talent cultivation demand can be met through new specialty construction, specialty resource sharing, inter-academic resource sharing, school-enterprise cooperation and other modes. Secondly, the specialty can meet the employment market demand, and the Building Electricity and Intelligent Specialty has been set in 89 universities nationwide, and within Heilongjiang Province, there are merely Harbin Institute of Technology and our school setting this specialty, and Harbin Institute of Technology mainly cultivates research-type talents, and will not directly import them to the talent market, so the talent gap for the specialty is huge, and currently, the freshmen and sophomores at school are almost fully "booked". Finally, teacher strength and specialty intersecting can meet the growth of new engineering. Our school has the soil to develop Building Electricity and Intelligent Specialty, and all the resources and talents of Civil Engineering Specialty, Urban Underground Space Specialty, Computer Science and Technology Specialty and Electronic Information Engineering Specialty are the effective assistance for the development of Building Electricity and Intelligent Specialty. Thus, the problem demanding prompt solution is how to build characteristic new engineering talent cultivation research about Building Electricity Specialty in local universities and radiate to talent cultivation scheme.

\section{B. Weakness Analysis}

Although local universities have certain strengths for developing new specialties, there are still some insufficiencies. Firstly, new specialty-oriented course groups have insufficient integrating degree with local enterprises. "New engineering" has brought new opportunities for the development of local undergraduate universities. On one hand, local universities can effectively sort out existing specialty configurations, make an overall arrangement for the construction of strategic emerging industry related specialties, and then use new specialties to activate traditional specialties; as can be seen from the existing specialty setup of Harbin University, the Engineering College currently has Civil Engineering Specialty, Urban Underground Space Specialty, Electronic Information Engineering Specialty, Physics Specialty and Building Electricity and Intelligent Specialty; in 2014 and 2015, through two years of endeavors, the newly applied Building Electricity and Intelligent Specialty closely combined various specialties, driven the development of Electronic Information Engineering Specialty, enriched the discipline constitution of Civil Engineering Specialty, and this has motivated the development of relevant traditional specialties to a large extent. Secondly, the talent cultivation objective of new specialty was unclear. Specifically speaking, new characteristic specialties should further define talent cultivation objective, and formulate sounder course system, to serve the development of local economic society; as can be seen from the national scale, the cultivation of talents majoring in building electricity mainly analyzes several conditions from the emphasis on automation setup, the emphasis on computerdriven smart home and the emphasis on civil engineering, but the civil engineering, electronics and computer specialties of our school are not strong enough to comprehensively drive the direction of building electricity and intelligent, especially the grasp of employment market, which is insufficient. Finally, the matching laboratory facilities of characteristic specialtyoriented courses are imperfect, and the construction of sound specialty laboratory, internship and practical training base can improve students' practical capacity, and then employment can be regarded as the orientation in combination with the current 
status of local enterprises, to accelerate the cultivation of urgently needed professional talents. During the current period, the specialty has signed internship base agreement with Harbin Metro Group, Heat Supply Group, etc., so as to offset students' insufficiency in practical links, but the grasp of employment prospect is still insufficient.

\section{Opportunity Analysis}

Under the background of new engineering, the construction of characteristic specialty-oriented courses in local universities has good development opportunities, and is specifically stated from national policy, local economic development, and specialty development. Firstly, the national policy encourages to promote engineering education reform innovation, and then on February 18, 2017, the Ministry of Education convened Higher Engineering Education Development Strategy Seminar at Fudan University, discussed about the contained characteristics of new engineering, the construction of new engineering, the selection of development path and other issues; after that, the Ministry of Education published the Notice of the Department of Higher Education for the Ministry of Education about Carrying out the Research and Practice of "New Engineering", and hoped that universities of all places can carry out the research practical activities of the "new engineering"; secondly, the local economic development requires characteristic specialty development and then on April 8, 2017, the Ministry of Education convened the new Engineering Construction Seminar at Tianjin University, and above 60 universities jointly discussed about the new engineering construction vision and actions. The Ministry of Education prepared to divide universities into engineering advantage universities, comprehensive universities, and local universities, to carry out the research, of which local universities need to use the local resources, dock with the development demand of local economic society and the enterprise technology innovation requirements, deepen the integration of production and education, school-enterprise cooperation, collaborated talent cultivation, promote the transformation and upgrading of traditional engineering, carry out the research and practice of new engineering in local universities. Finally, the establishment of characteristic specialty-oriented course groups is good for the specialty structure adjustment and coordinated development. During the current period, Harbin Municipal Government energetically supports the development of Harbin University, requests to cultivate applied talents in combination with the local economic development; Building Electricity and Intelligent Specialty is the representative of characteristic applied specialties, with better development opportunities.

\section{Threat Analysis}

Any reform can have restriction factors and negative effect, and the establishment of new directional course groups can also bring certain threats to professional development. Firstly, it may cause the narrow employment surface of students, and specifically, in case of conducting ordered cultivation as per enterprise demands, this is equivalent to the directional cultivation of students, but today when talents flow fast, the further development of students is restricted equivalently; secondly, excessive applied directional course groups may let students loose the opportunity to pursue graduate study, and although it is positioned at applied talent cultivation, there are still many excellent students, who will become graduate students with strong practical capacity, while the excessive course reform and the deletion of contents have enlarged students' contents for taking graduate school examination; finally, it has restricted specialty development to some extent, and the excessive emphasis on school-enterprise cooperation has increased the dependence degree of specialty for enterprises. During the current period, when comparing the new specialty and traditional specialty, the difficulty for students to take graduate school examination and study continuously is bigger, and it is requested to make crossspecialty examination preparation, which has restricted the cultivation of excellent talents to some extent.

\section{SUMMARY}

The Building Electricity and Intelligent Specialty is the characteristic emerging specialty in local universities under the background of new engineering, and its directional course group construction is the development path for distinguishing it from traditional specialty. This paper takes the Building Electricity and Intelligent Specialty as the example, applies SWOT analysis method to analyze the directional course group construction of local universities under the background of new engineering from strength analysis, weakness analysis, opportunity analysis and threat analysis respectively, and it can be seen that, the setup of directional course shall meet the professional development, conform to the local economic mode, break through professional barrier, and transport composite engineering talents for local economy; meanwhile, it is also requested to seize professional connotation, lay an engineering basis for students, and provide a broader development space for students.

\section{ACKNOWLEDGMENT}

About the Author: LUO Qiubin (1970.6-), female, the Professor and Doctor majoring in Building Electricity and Intelligent of School of Technology, Harbin University, and the main research direction is nonlinear system modeling and control, and higher education research;

Fund Assistance: It is supported by Heilongjiang Province Educational Scientific Planning Key Project (GBB1318063), Heilongjiang Province Educational Scientific Planning Project (GJC1316149) and the 13th Five-year Higher Education Scientific Research Project (16Q170, 16Q172). 


\section{REFERENCES}

[1] LIN Jian. Multi-disciplinary Integrated Freshman Engineering Construction [J]. Researches in Higher Education of Engineering, 2018 (01): 32-45.

[2] LIANG Liming, LIN Yuanzhang, WU Jian, YANG Guoliang, and WENG Falu. Exploration and Analysis about the Local Undergraduate College Reform Development Path under the Background of "New Engineering" $[\mathrm{J}]$. Journal of Jiangxi University of Science and Technology, 2017, 38 (06): 60-64.

[3] CHENG Yan, JIN Xiao, LIN Yalan, CHEN Si, ZHANG Yongyuan, MOU Xinli. SWOT Analysis on the Economic Management Courses of Local Universities under the Background of "New Engineering" [J]. Shandong Chemical Industry, 2017, 46 (23): 150-151.

[4] GU Peihua. New Engineering and New Mode: Concept, Framework and Implementation Approach [J]. Researches in Higher Education of Engineering, 2017 (06): 1-13.

[5] ZHANG Haisheng. Practical Exploration and Classified Development of "New Engineering" Construction in Universities of Our Country [J]. Chonging High Education Research, 2018, 6 (01): 41-55.

[6] LIN Jian. Deeply and Solidly Promoting the Construction of New Engineering - the Research of New Engineering as well as the Organization and Implementation of Practical Projects [J]. Researches in Higher Education of Engineering, 2017 (05):18-31.

[7] LU Guodong and LI Tuoyu. Reflection on the Construction and Development Path of New Engineering [J]. Researches in Higher Education of Engineering, 2017 (03): 20-26.

[8] LIN Jian. New Engineering Construction: Powerfully Creating "Excellence Plan" Upgrading Edition [J]. Researches in Higher Education of Engineering, 2017 (03): 7-14.

[9] LIN Jian. Chinese New Engineering Construction Facing the Future [J]. Tsinghua Journal of Education, 2017, 38 (02):26-35. 